\title{
The Extrathyroidal Conversion Rate of Thyroxine to Triiodothyronine in Normal Man
}

\author{
Constance S. Pittman, Joseph B. Chambers, Jr., and \\ Virginia H. Read \\ From the Department of Medicine, University of Alabama Medical Center, \\ Birmingham, Alabama 35233
}

\begin{abstract}
A в S T R A C T Eight normal subjects were administered tracer amounts of a ${ }^{14} \mathrm{C}$-labeled thyroxine, L-[tyrosyl$\left.{ }^{14} \mathrm{C}\right] \mathrm{T}_{4}$, by multiple injections. Then serial blood samples were collected for isolation of the thyroxine, triiodothyronine, and tetraiodothyroacetic acid fractions by a combination of column and paper chromatographies. The chromatographic artifacts were corrected by adding to the sera a purified ${ }^{3} \mathrm{H}$-labeled thyroxine, $\mathrm{D}, \mathrm{L}-\left[\alpha, \beta-{ }^{3} \mathrm{H}\right] \mathrm{T}_{4}$ immediately after the separation of sera from blood. $1-2 \%$ of the serum ${ }^{14} \mathrm{C}$ radioactivity was observed in the triiodothyronine fraction and $2-4 \%$ of the serum ${ }^{14} \mathrm{C}$ radioactivity was observed in the tetraiodothyroacetic acid fraction. Complete kinetic studies of thyroxine and triiodothyronine were compared in the same individual in four of the subjects. The extrathyroidal conversion rates of thyroxine to triiodothyronine were calculated from data obtained during both the injection and the postinjection periods as functions of the ${ }^{14} \mathrm{C}$-labeled thyroxine and triiodothyronine remaining in the body at time $t$ and their fractional turnover rates. The average daily rate of the extrathyroidal conversion of thyroxine to triiodothyronine was $4 \%$ of the extrathyroidal thyroxine pool or $33 \%$ of the total thyroxine production. The amount of triiodothyronine generated by this pathway $(22 \mu \mathrm{g} / \mathrm{day})$ was found to contribute $31 \%$ of the extrathyroidal triiodothyronine pool or $41 \%$ of the daily triiodothyronine production. This pathway is a major source of triiodothyronine production. The extrathyroidal conversions of thyroxine to triiodothyronine and tetraiodothyroacetic acid are major metabolic pathways of thyroxine in normal man.
\end{abstract}

This work was presented in part at the American Society for Clinical Investigation, 3 May 1970 in Atlantic City, N. J., and at the 6th International Thyroid Conference, 22 June 1970 in Vienna, Austria.

Dr. Read is a special postdoctoral fellowship awardee granted by the U. S. Public Health Service.

Received for publication 19 August 1970 and in revised form 28 January 1971.

\section{INTRODUCTION}

Since the presence of triiodothyronine $\left(\mathrm{T}_{3}\right)^{1}$ in human plasma was first reported in 1952, the source of this circulating hormone has never been clearly defined (1). It is known that some triiodothyronine is released by the thyroid gland into the blood. At least in the lower animals, the concentration of triiodothyronine is higher in the venous effluent than the arterial blood of the thyroid $(2,3)$. The possibility of extrathyroidal deiodination of thyroxine $\left(\mathrm{T}_{4}\right)$ to triiodothyronine had also been entertained by many investigators. However, in the early human studies, the attempts to identify ${ }^{131}$ I-labeled $T_{3}$ following a single injection of ${ }^{131}$ I-labeled $\mathrm{T}_{4}$ only yielded equivocal results $(4,5)$. Volpert, Greenberg, and Werner found triiodothyronine in both normal pituitary and transplanted pituitary tumor of mice after the injection of ${ }^{131}$ I-labeled thyroxine (6). Albright, Larson, and Tust detected triiodothyronine after incubating ${ }^{131}$ I-labeled thyroxine with rat kidney tissue (7). While there were such exceptions, most animal studies by either in vivo or in vitro techniques also failed to substantiate deiodination of $\mathrm{T}_{4}$ as a significant pathway that gives rise to circulating $T_{3}(6-8)$. More recently Braverman, Ingbar, and Sterling analyzed the total serum $T_{4}$ and $T_{3}$ in hypothyroid patients maintained on pharmacological doses of L-thyroxine (9). The $T_{3}: T_{4}$ ratios in their sera were found to be higher than the ratio in the ingested $\mathrm{L}$-thyroxine preparation. These same investigators also administered multiple injections of ${ }^{125}$ I-labeled thyroxine to two athyreotic patients. Approximately $1-2 \%$ of the serum radioactivity was found to be in the triiodothyronine fraction and twice that in the tetraiodothyroacetic acid (Tetrac) fraction. This study strongly suggested the presence of extrathyroidal conversion of $T_{4}$ to $T_{3}$ in man. In a study by Pittman, Nakafuji, and Read in normal men, ${ }^{14} \mathrm{C}$ -

\footnotetext{
${ }_{1}$ Abbreviations used in this paper: $\mathrm{K}$, fractional turnoverrate; $T_{3}$, triiodothyronine; $T_{4}$, thyroxine; Tetrac, tetraiodothyroacetic acid; $V_{d}$, volume of distribution.
} 
labeled $\mathrm{T}_{3}$ and Tetrac were also regularly observed after repeated intravenous injections of ${ }^{14} \mathrm{C}$-labeled $\mathrm{T}_{4}(10)$. The present report contains our measurement of the rate of this extrathyroidal conversion of $T_{4}$ to $T_{3}$ in similarly prepared normal subjests. $\mathrm{T}_{4}$ and $\mathrm{T}_{3}$ kinetic studies were compared in the same individuals in order to define the biological significance of the pathway of extrathyroidal conversion of $T_{4}$ to $T_{3}$ in man.

\section{METHODS}

Materials. Two types of radiothyroxines were used in the studies. One radiothyroxine was labeled with ${ }^{14} \mathrm{C}$ in the nonphenolic ring and the alanine side chain, $L-\left[\right.$ tyrosyl- $\left.{ }^{14} \mathrm{C}\right] \mathrm{T}_{4}$. It was synthesized by the method of Shiba and Cahnmann by Amersham-Searle Corp., Arlington Heights, Ill. and it had a specific activity of $135 \mathrm{mCi} / \mathrm{mmole}(11)$. The L-[tyrosyl- ${ }^{14} \mathrm{C}$ ] $T_{4}$ was used to calculate the $T_{4}$ to $T_{3}$ conversion rates. The other radiothyroxine was labeled with ${ }^{3} \mathrm{H}$ in the alpha and beta carbons of the side chain, $\mathrm{D}, \mathrm{L}-\left[\alpha, \beta-{ }^{3} \mathrm{H}\right] \mathrm{T}_{4}$, with a specific activity of $125 \mathrm{mCi} / \mathrm{mmole}$. The $\mathrm{D}, \mathrm{L}-\left[\alpha, \beta-{ }^{3} \mathrm{H}\right] \mathrm{T}_{4}$ was synthesized by Dr. J. Nunez with the method of Nunez, Jacquemin, and Roche (12). The sample contained primarily L-thyroxine but it was not free of some $\mathrm{D}$-thyroxine. The $\mathrm{D}, \mathrm{L}-\left[\alpha, \beta^{-}{ }^{3} \mathrm{H}\right] \mathrm{T}_{4}$ was used only as a methodological control in the correction for artifactual $T_{4}$ deiodination and for the calculation of $T_{4}$ recoveries during our chromatographic manipulations. In addition, a ${ }^{131} I$-labeled triiodothyronine, $L-\left[3^{\prime}-{ }^{131} I\right] T_{3}$ was purchased from the Abbott Laboratories, North Chicago, Ill., specific activity $1.79 \times 10^{4} \mathrm{mCi} / \mathrm{mmole}$. The purity of radioactive $\mathrm{T}_{4}$ and $\mathrm{T}_{3}$ was $98 \%$ or greater before use. They were prepared for injection in a sterile solution of $1 \%$ ethanol, $0.9 \%$ scdium chloride, and $1 \%$ human albumin as described previously (13). Every thyroxine dose was chromatographed in at least two solvent systems and the presence of triiodothyronine was assayed directly in a liquid scintillation counter as described below. Two $D, L-\left[\alpha, \beta-{ }^{3} \mathrm{H}\right] \mathrm{T}_{4}$ standards were prepared and they contained 0.52 and $0.50 \%$ of ${ }^{3} \mathrm{H}$-labeled triiodothyronine. Five injection doses of $\mathrm{D}, \mathrm{L}-\left[\alpha, \beta{ }^{3} \mathrm{H}\right] \mathrm{T}_{4}$ were prepared. The range of ${ }^{3} \mathrm{H}$-labeled triiodothyronine contained in these preparations was $0.46-0.81 \%$. Seven injection doses of $\mathrm{L}$-[tyrosyl- ${ }^{14} \mathrm{C}$ ] $\mathrm{T}_{4}$ were prepared. The range of ${ }^{14} \mathrm{C}$-labeled triiodothyronine detected in these doses was $0.59-0.82 \%$.

Subjects. Studies were carried out in eight young, healthy male subjects free of any past history or family history of thyroid disorder. The details of their clinical information are listed in Table I. Throughout the experiment the subjects were housed in the Clinical Research Center of the University of Alabama Medical Center. Each subject was given daily intravenous injections of $\mathrm{L}-[$ tyrosyl-14 $\mathrm{C}] \mathrm{T}_{4}$ for 10 days. The total $\mathrm{T}_{4}$ dose was 8-11 $\mu \mathrm{g}$ per day. Throughout the experiment serial blood samples were taken. In addition, 24-hr urines and feces were collected for radioisotope recoveries. On the 20th day of experiment, an intravenous injection of $D, L-\left[\alpha, \beta-{ }^{3} \mathrm{H}\right] \mathrm{T}_{4}$ was given to four of the subjects $(97.4 \mu \mathrm{g})$. The $\mathrm{D}, \mathrm{L}-\left[\alpha, \beta-{ }^{3} \mathrm{H}\right] \mathrm{T}_{4}$ experiment was carried out to determine the rate at which the extrathyroidal conversion of $T_{4}$ to $T_{3}$ reaches an equilibrium. During the 24th-27th days of experiment these same four subjects were given Lugol's solution orally, five drops, t.i.d. (three times a day). They were given $200 \mu \mathrm{Ci}$ of $L-\left[3^{\prime}-131 \mathrm{I}\right] \mathrm{T}_{\mathrm{z}}$ intravenously in one injection for the kinetic studies of $T_{3}$. During the studies with $\mathrm{D}, \mathrm{L}-\left[\alpha, \beta-{ }^{3} \mathrm{H}\right] \mathrm{T}_{4}$ and $\mathrm{L}-\left[3^{\prime}-{ }^{131} \mathrm{I}\right] \mathrm{T}_{3}$, the collections of blood, urine, and feces were made every $12 \mathrm{hr}$.

Laboratory procedures. Sera were separated immediately after blood collection. Into those samples which did not contain previously injected $\mathrm{D}, \mathrm{L}-\left[\alpha, \beta-{ }^{3} \mathrm{H}\right] \mathrm{T}_{4}$, a small amount of purified $\mathrm{D}, \mathrm{L}-\left[\alpha, \beta-{ }^{3} \mathrm{H}\right] \mathrm{T}_{4}$ was added as a control for $\mathrm{T}_{4}$ recovery and for artifactual $\mathrm{T}_{3}$ production. The amounts of ${ }^{3} \mathrm{H}$-labeled $\mathrm{T}_{3}$ found at the end of all chromatographic manipulations were used to correct for the in vitro $T_{4}$ to $T_{3}$ conversion. For samples which contained previously injected $\mathrm{D}, \mathrm{L}-\left[\alpha, \beta-{ }^{3} \mathrm{H}\right] \mathrm{T}_{4}$, the ${ }^{3} \mathrm{H}-$ labeled $T_{3}$ found in the blood $10 \mathrm{~min}$ after the injection of $\mathrm{D}, \mathrm{L}-$ $\left[\alpha, \beta{ }^{3} \mathrm{H}\right] \mathrm{T}_{4}$ was used for similar correction.

The $T_{4}, T_{3}$, and Tetrac fractions were isolated from serum by a combination of column and filter-paper chromatographies (14). The serum samples were deproteinized on a resin column, Dowex AG, W-X2 (Dow Chemical Co., Midland, Mich.) $\left(\mathrm{H}^{+}\right.$form). After washing the column with water and $0.15 \mathrm{M}$ ammonium acetate, the $T_{4}, T_{3}$, and Tetrac fractions were eluted with $7.4 \mathrm{~N}$ ammonium hydroxide. The eluent was condensed by lyophilization and applied on a No. 3 Whatman paper. The two-dimensional chromatogram was developed in a solvent of hexane, tertiary amyl alcohol, and $2 \mathrm{~N}$ ammonia $(1: 5: 6)$ in a descending system for the first direction and then in an ascending system in the second direction. A small amount of carrier $T_{3}(5 \mu \mathrm{g} / \mu \mathrm{l})$ was added into the condensed eluent to facilitate visualization of the $T_{3}$ area on the paper chromatogram under ultraviolet light. $\mathrm{T}_{4}$ was present in adequate amount to be detected by ultraviolet light without the use of carrier $T_{4}$. The $T_{4}, T_{3}$, and Tetrac areas were cut out in $2 \times 0.5 \mathrm{~cm}$ strips. The mean $\mathrm{T}_{4}$ recovery was $54.8 \%$ with a range of $45.8-62.8 \%$. For each run of serum, a tracer amount of a purified $\mathrm{L}-\left[3^{\prime}-131 \mathrm{I}\right] \mathrm{T}_{3}$ was added to a portion of the same sample and the paired portions were carried through the entire

TABLE I

Clinical Information of the Subjects

\begin{tabular}{|c|c|c|c|c|c|c|c|}
\hline \multicolumn{3}{|c|}{ Patients, age, and sex } & $\begin{array}{l}\text { Thyroidal } \\
\text { uptake } \\
\text { of }{ }^{131} \text { I }\end{array}$ & $\begin{array}{c}\text { Total } \\
\text { serum } \\
T_{4}\end{array}$ & $\begin{array}{c}\text { Total } \\
\text { serum } \\
T_{3}\end{array}$ & $\begin{array}{l}T_{4}: T_{3} \\
\text { ratios }\end{array}$ & $\begin{array}{c}\mathrm{L}-[\text { tyrosyl-14 } \mathrm{C}] \\
\text { T، inj. }\end{array}$ \\
\hline \multicolumn{3}{|l|}{$y r$} & $\% 24 h r^{-1}$ & $\mu \mathrm{g} / 100 \mathrm{ml}$ & $n g / 100 m l$ & & $d p m \times 10^{6} d a y^{-1}$ \\
\hline J. McD. & 22 & $\mathbf{M}$ & 17.8 & 8.0 & 230 & 35 & 3.090 \\
\hline D. D. & 21 & M & 7.8 & 4.5 & 140 & 32 & 7.713 \\
\hline D. V. & 21 & $\mathbf{M}$ & 32.7 & 6.5 & 165 & 39 & 4.480 \\
\hline B. H. & 23 & $\mathbf{M}$ & 36.1 & 7.0 & 160 & 44 & 4.480 \\
\hline J. Mu. & 22 & $\mathbf{M}$ & 20.2 & 6.5 & 210 & 31 & 4.452 \\
\hline D. G. & 22 & $\mathrm{M}$ & 16.7 & 5.5 & 190 & 29 & 4.279 \\
\hline J. S. & 22 & M & 17.5 & 4.2 & & & \\
\hline J. Ma. & 23 & $\mathbf{M}$ & 22.8 & 4.9 & & & \\
\hline
\end{tabular}


chromatographic procedure simultaneously in a parallel fashion. The $T_{3}$ recovery was calculated from the recovered $\mathrm{L}-\left[3^{\prime}-{ }^{131} \mathrm{I}\right] \mathrm{T}_{3}$. The over-all $\mathrm{T}_{3}$ recovery by this method was $17.2-31.8 \%$. In the present study some serum samples were controlled by $\mathrm{D}, \mathrm{L}-\left[\alpha, \beta-{ }^{3} \mathrm{H}\right] \mathrm{T}_{4}$. Both the trace amounts of ${ }^{3} \mathrm{H}-\mathrm{T}_{4}$ contaminant and the trace amounts of ${ }^{3} \mathrm{H}$-labeled $\mathrm{T}_{3}$ which was produced by the in vitro deiodination of $D, L-\left[\alpha, \beta-{ }^{8} \mathrm{H}\right] \mathrm{T}_{4}$, contributed ${ }^{3} \mathrm{H}$ activity to the $\mathrm{T}_{3}$ zone on paper chromatograms. The per cent of ${ }^{3} \mathrm{H}$ radioactivity detected in the $T_{3}$ zone was assumed to be the same as the percent of ${ }^{14} \mathrm{C}$ radioactivity contributed by the same artifacts which were corrected for in our calculation of ${ }^{14} \mathrm{C}-\mathrm{T}_{3}$. The over-all recovery of thyroxine calculated from the $D, L-\left[\alpha, \beta-{ }^{3} \mathrm{H}\right]$ $\mathrm{T}_{4}$ standard was $7.9-19.0 \%$.

The ${ }^{14} \mathrm{C}$ and ${ }^{3} \mathrm{H}$ activities were assayed in a dioxane scintillator ( $1 \%$ PPO, $0.05 \%$ POPOP, and $5 \%$ naphthalene) with a liquid scintillation counter (Nuclear-Chicago Corporation, Des Plaines, Ill.). The gamma radioactivity of ${ }^{131}$ I was assayed in a well scintillation counter (Nuclear-Chicago Corporation, Des Plaines, Ill.).

The half-times of $\mathrm{T}_{4}$ were obtained from the ${ }^{14} \mathrm{C}$ data $24 \mathrm{hr}$ after the last injection of $\mathrm{L}-\left[\right.$ tyrosyl $\left.-{ }^{14} \mathrm{C}\right] \mathrm{T}_{4}$. The disappearance of ${ }^{14} \mathrm{C}$ radioactivity in blood was followed for 9-12 days during which time five to seven samples were collected from each subject for the calculation of half-times.

In the study of $T_{3}$ kinetics, the ${ }^{131} \mathrm{I}$ activities in both the native serum and the protein precipitate were assayed. The latter was used in our calculation. The serum was precipitated by the following procedure. To $1.0 \mathrm{ml}$ of serum was first added $25 \mu \mathrm{g} / \mathrm{ml}$ of carrier sodium iodide and enough propylthiouracil to make a $10^{-5} \mathrm{M}$ solution, followed by $1.0 \mathrm{ml}$ of cold $20 \%$ trichloroacetic acid. The resulting precipitate was washed three times with cold $5 \%$ trichloroacetic acid.

The measurements of the total serum $T_{4}$ and $T_{3}$ were carried out by the Boston Medical Laboratory, Waltham, Mass. The serum $T_{4}$ was measured by a modification of the method of Murphy and Pattee (15). The serum $\mathrm{T}_{3}$ was measured according to a modified method of Sterling, Bellabarba, Newman, and Brenner (14).

Calculation. The serum radioactivity was plotted as a function of time. The half-time $\left(t \frac{1}{2}\right)$ of $T_{4}$ or $T_{3}$ was obtained from the respective linear regression. The fractional turnoverrate $(K)$ and the zero time volume of distribution $\left(V_{d}\right)$ were calculated by a method similar to that described by Ingbar and Freinkel (16). The total body pool was derived from the product of the serum concentration and the volume of distribution. The daily production rate (or disposal rate) was calculated from the product of the serum concentration, the volume of distribution, and the fractional turnover-rate of $T_{4}$ or $T_{3}$. In the study of $T_{3}$ kinetics, the problem of iodoproteins that arises as a product of $T_{3}$ degradation was avoided by using only the data collected between $24-72 \mathrm{hr}$ after an injection of $\mathrm{L}-\left[3^{\prime}-{ }^{131} \mathrm{I}\right] \mathrm{T}_{3}$ (17).

The kinetics in the extrathyroidal conversion of $T_{4}$ to $T_{3}$ are calculated by the following:

$\mathrm{A}=$ the daily injection dose of radiothyroxin in $\mathrm{dpm}$.

$\left[\mathrm{T}_{4}\right]=$ the amount of injected $\mathrm{L}$-[tyrosyl $\left.{ }^{14} \mathrm{C}\right] \mathrm{T}_{4}$ in the body in dpm at time $t$.

$\left[\mathrm{T}_{3}\right]=$ the amount of $\mathrm{L}-\left[\right.$ tyrosyl $\left.-{ }^{14} \mathrm{C}\right] \mathrm{T}_{3}$ in the body in $\mathrm{dpm}$ at time $\mathrm{t}$.

$\mathrm{K}_{\mathbf{4}}=$ the fractional turnover-rate of thyroxine, per day.

$\mathbf{K}_{\mathbf{8}}=$ the fractional turnover-rate of triiodothyronine, per day.

$\lambda=$ the extrathyroidal conversion rate of thyroxine to triiodothyronine per day.

$\mathrm{t}^{*}=$ the time of last injection of radiothyroxin in days.

$\mathrm{t}=$ the time of blood sample collection in days.
In this calculation the following assumptions are made:

(a) $\mathrm{K}_{3}, \mathrm{~K}_{4}$, and $\lambda$ are independent of both time and the amount of $T_{3}$ and $T_{4}$ present.

(b) $\lambda / K_{4}$ is close to zero.

(c) A units of labeled $\mathrm{T}_{4}$ are administered daily for $\mathrm{t}^{*}$ days.

$$
\frac{\mathrm{d}\left[\mathrm{T}_{4}\right]}{\mathrm{dt}}=\mathrm{A}-\mathrm{K}_{4}\left[\mathrm{~T}_{4}\right] \text {. }
$$

For $A \neq 0$, the solution of (1) is

$$
\left[\mathrm{T}_{4}\right]=\frac{\mathrm{A}}{\mathrm{K}_{4}}\left(1-\mathrm{e}^{-\mathrm{K}_{4} \mathrm{t}}\right) .
$$

For $A=0$, i.e. for $t>t^{*}$, the solution to (1) is

$$
\left[\mathrm{T}_{4}\right]=\mathrm{Ce}^{-\mathrm{K}_{4} \mathrm{t}}
$$

where $\mathrm{C}$ must be evaluated from the initial conditions. In this case, the initial conditions are that at $t=t^{*}\left[T_{4}\right]$ is given by, from (2), $A\left(1-e^{-K_{4} t^{*}}\right) / K_{4}$. Using this, equation (3) becomes

$$
\left[\mathrm{T}_{4}\right]=\frac{\mathrm{A}}{\mathrm{K}_{4}}\left(1-\mathrm{e}^{-\mathrm{K}_{4} \mathrm{t}^{*}}\right) \mathrm{e}^{\mathrm{K}_{4}\left(\mathrm{t}^{*-} \mathrm{t}\right)} .
$$

The extrathyroidal conversion of $T_{4}$ to $T_{3}$ can be described by

$$
\frac{\mathrm{d}\left[\mathrm{T}_{3}\right]}{\mathrm{dt}}=\lambda\left[\mathrm{T}_{4}\right]-\mathrm{K}_{3}\left[\mathrm{~T}_{3}\right]
$$

As was the case for $\left[\mathrm{T}_{4}\right]$, the solution of (5) will have one of two forms, depending on whether or not $\mathrm{A}=0$. For $\mathrm{A} \neq 0$, the initial condition is that $\left[\mathrm{T}_{3}\right]=0$ for $t=0$, and the solution to (5) is

$$
\begin{aligned}
& {\left[\mathrm{T}_{3}\right]=\frac{\lambda A}{\mathrm{~K}_{3} \mathrm{~K}_{4}\left(\mathrm{~K}_{3}-\mathrm{K}_{4}\right)} } \\
& \quad \times\left[\mathrm{K}_{3}\left(1-\mathrm{e}^{-\mathrm{K}_{4} \mathrm{t}}\right)-\mathrm{K}_{4}\left(1-\mathrm{e}^{-\mathrm{K}_{3} t}\right)\right] .
\end{aligned}
$$

For $A=0$, the initial condition is that, at $t=t^{*},\left[T_{3}\right]$ is given by (6), with $t^{*}$ replacing $t$. Using this, the solution to (5) becomes

$$
\begin{aligned}
{\left[\mathrm{T}_{3}\right]=\frac{\lambda A}{\mathrm{~K}_{3} \mathrm{~K}_{4}\left(\mathrm{~K}_{3}-\mathrm{K}_{4}\right)}\left[\mathrm{K}_{3}\left(1-\mathrm{e}^{-\mathrm{K}_{4} \mathrm{t}^{*}}\right) \mathrm{e}^{-\mathrm{K}_{4}\left(\mathrm{t}-\mathrm{t}^{*}\right)}\right.} \\
\left.-\mathrm{K}_{4}\left(1-\mathrm{e}^{-\mathrm{K}_{3} \mathrm{t}^{*}}\right) \mathrm{e}^{-\mathrm{K}_{3}\left(\mathrm{t}-\mathrm{t}^{*}\right)}\right] .
\end{aligned}
$$

For $\mathrm{t} \leq \mathrm{t}^{*}$, the extrathyroidal conversion rate, $\lambda$, can be found, after dividing (6) by (2), as

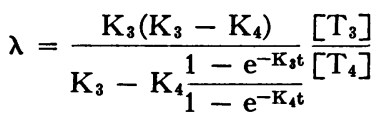

For $\mathrm{t}>\mathrm{t}^{*}, \lambda$ can be found by dividing (7) by (4).

$$
\lambda=\frac{K_{3}\left(K_{3}-K_{4}\right)}{K_{3}-K_{4}\left(\frac{e^{K_{3} t^{*}}-1}{e^{K_{4} t^{*}}-1}\right) e^{-\left(K_{3}-K_{4}\right) t}} \frac{\left[T_{3}\right]}{\left[T_{4}\right]}
$$

\section{RESULTS}

The clinical information of our subjects are summarized in Table I. Our subjects were given 10 daily injections of $\mathrm{L}$-[tyrosyl $\left.-{ }^{14} \mathrm{C}\right] \mathrm{T}_{4}$. During the entire 20 days of study the average ${ }^{14} \mathrm{C}$ recovery from urine was $37.6 \%$ of the injected dose with a range of $27.7-50.3 \%$. The fecal collections from five of the eight subjects were complete. The average recovery of ${ }^{14} \mathrm{C}$ from feces was $13.0 \%$ of the injected dose with a range of $9.2-14.4 \%$. Fig. 1 shows the cumulative and daily recoveries of ${ }^{14} \mathrm{C}$ 


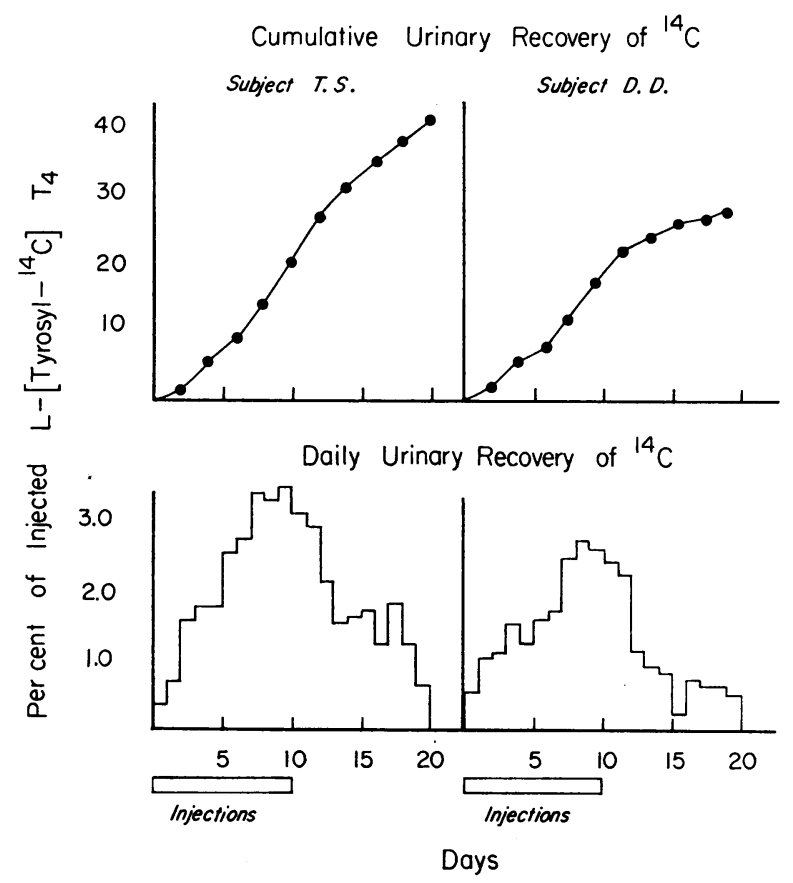

Figure $1{ }^{14} \mathrm{C}$ recoveries from urine. Each subject was given $\mathrm{L}$-[tyrosyl- $\left.{ }^{14} \mathrm{C}\right] \mathrm{T}_{4} 8-11 \mu \mathrm{g} /$ day intravenously for 10 days.

from urine of subjects J. S. and D. D. This pattern of urinary recovery was typical of the remaining subjects of the group.

In all serum samples studied, ${ }^{14} \mathrm{C}$ radioactivity was consistently found in the $\mathrm{T}_{4}, \mathrm{~T}_{3}$, and Tetrac fractions. The ${ }^{14} \mathrm{C}$-labeled Tetrac was always found in equal or slightly larger amounts than the ${ }^{14} \mathrm{C}$-labeled $\mathrm{T}_{3}$. The ${ }^{14} \mathrm{C}$ radioactivity in the $\mathrm{T}_{3}$ fraction represented 1.56 $\pm 0.50 \%$ of the total ${ }^{14} \mathrm{C}$ radioactivity in serum. The recovery of Tetrac was not measured. Of the total radioactivity applied to the chromatogram paper, $0.4-4.3 \%$ was found in the Tetrac fraction.

In all the subjects studied trace amounts of $\mathrm{D}, \mathrm{L}-\left[\alpha, \beta-{ }^{3} \mathrm{H}\right] \mathrm{T}_{4}$ were added to sera either in vitro or in vivo as a control. The need of such a control is shown in Fig. 2. Subject J. McD. had previously been equilibrated with $\mathrm{L}$-[tyrosyl-14$\left.{ }^{14} \mathrm{C}\right] \mathrm{T}_{4}$. Then he was given an injection of $\mathrm{D}, \mathrm{L}-\left[\alpha, \beta{ }^{3} \mathrm{H}\right] \mathrm{T}_{4}$. A serum sample drawn 10 min after the injection of $\mathrm{D}, \mathrm{L}-\left[\alpha, \beta-{ }^{3} \mathrm{H}\right] \mathrm{T}_{4}$ showed $0.27 \%$ ${ }^{3} \mathrm{H}$ activity in the $\mathrm{T}_{3}$ fraction which was likely due to the $\mathrm{D}, \mathrm{L}-\left[\alpha, \beta-{ }^{3} \mathrm{H}\right] \mathrm{T}_{3}$ in the injection dose, the $\mathrm{D}, \mathrm{L}-\left[\alpha, \beta{ }^{3} \mathrm{H}\right]$ $\mathrm{T}_{4}$ remaining in the $\mathrm{T}_{3}$ fraction and some $\mathrm{D}, \mathrm{L}-\left[\alpha, \beta-{ }^{3} \mathrm{H}\right]$ $\mathrm{T}_{3}$ formed artifactually in vitro. The serum study of a similarly prepared subject, B. H., is shown in Fig. 3 in which the ${ }^{3} \mathrm{H} /{ }^{14} \mathrm{C}$ ratios of the deproteinized serum, the $T_{4}$ and $T_{3}$ fractions are plotted as functions of time. The ${ }^{3} \mathrm{H} /{ }^{14} \mathrm{C}$ ratios of the deproteinized serum and of the $\mathrm{T}_{4}$ fraction remained nearly constant after the initial equilibration of $\mathrm{D}, \mathrm{L}-\left[\alpha, \beta_{-}{ }^{3} \mathrm{H}\right] \mathrm{T}_{4}$ with the body pool of
$\mathrm{T}_{4}$. The ${ }^{3} \mathrm{H} /{ }^{14} \mathrm{C}$ ratio in the $\mathrm{T}_{3}$ fraction rose and did not reach a plateau until $48 \mathrm{hr}$ after the injection of $D, L-\left[\alpha, \beta-{ }^{3} \mathrm{H}\right] \mathrm{T}_{4}$. If the ${ }^{3} \mathrm{H}$ activity in the $\mathrm{T}_{3}$ fraction was due to $\mathrm{T}_{3}$ contamination in the $\mathrm{D}, \mathrm{L}-\left[\alpha, \beta-{ }^{3} \mathrm{H}\right] \mathrm{T}_{4}$ dose and chromatographic artifacts, the ${ }^{3} \mathrm{H} /{ }^{14} \mathrm{C}$ ratio in the $\mathrm{T}_{3}$ fraction should have fallen or remained con-

Patient J. MC.D.

Serum

10 minutes postinjection of $D, L-\left[\alpha \beta-{ }^{3} H\right] T_{4}$
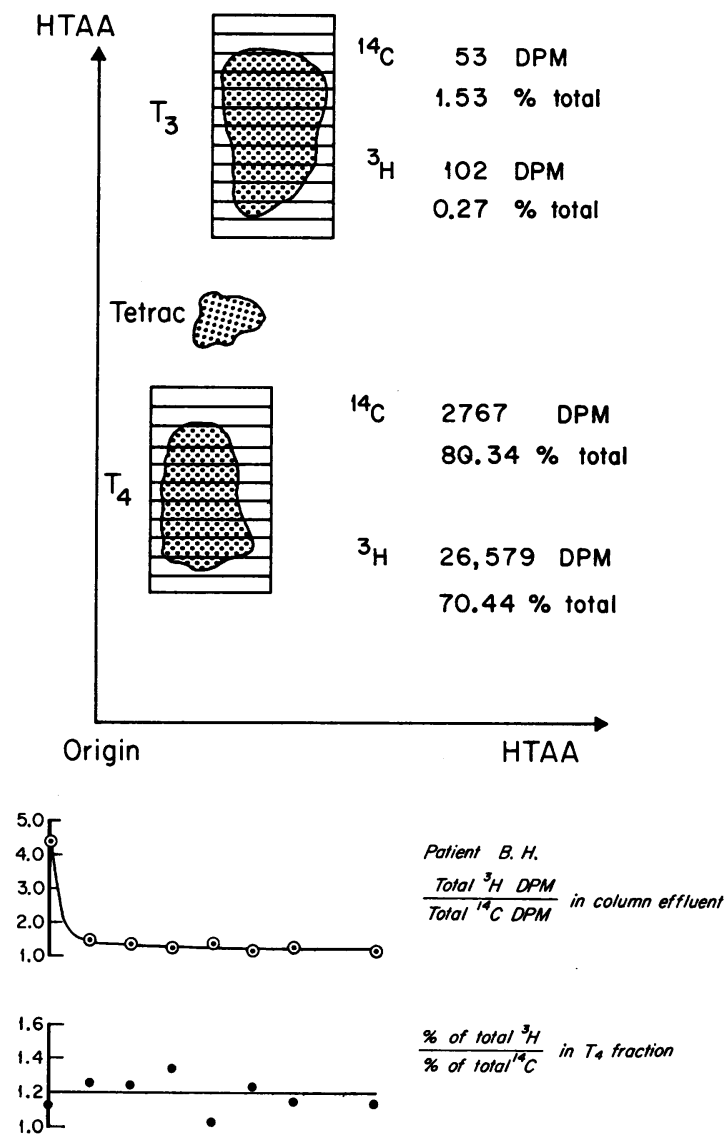

$\frac{\% \text { of } \text { total }^{3} \mathrm{H}}{\% \text { of } \text { total }^{14} \mathrm{C}}$ in $\mathrm{T}_{4}$ fraction

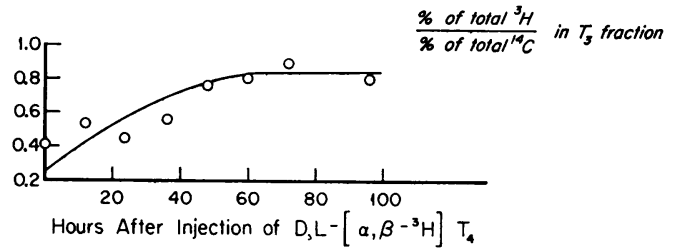

FIguREs 2 and 3 The subjects had been equilibrated with $\mathrm{L}-\left[\right.$ tyrosyl- $\left.{ }^{14} \mathrm{C}\right] \mathrm{T}_{4}$ previously and were then given one injection of $\mathrm{D}, \mathrm{L}-\left[\alpha, \beta-{ }^{3} \mathrm{H}\right] \mathrm{T}_{4}$, intravenously, $97.4 \mu \mathrm{g}$. Serial blood samples were collected. The two-dimensional paper chromatograms of the deproteinized sera were developed in a solvent system of hexane:tertiary amyl alcohol:2 $\mathrm{N}$ ammonium hydroxide in both directions. The $T_{4}$ and $T_{3}$ areas were cut out and assayed for ${ }^{14} \mathrm{C}$ and ${ }^{3} \mathrm{H}$ radioactivities. 
stant. Therefore, the radioactivity found in the $T_{3}$ fraction was contributed primarily by the in vivo conversion of radioactive $T_{4}$ to $T_{3}$ in addition to the artifacts mentioned before.

It is assumed that during chromatographic manipulations the ${ }^{3} \mathrm{H}$ and ${ }^{14} \mathrm{C}$-labeled thyroxines contributed similar fractions of their respective radioactivities to the $T_{3}$ area on paper chromatograms due to $T_{4}$ remaining in the $T_{3}$ fraction and due to $T_{4}$ to $T_{3}$ conversion in vitro. Therefore, the fraction of ${ }^{3} \mathrm{H}$ activity was used to correct for the contribution of ${ }^{14} \mathrm{C}$ due to these artifacts in the $T_{3}$ area. When this value was equal to or less than the labeled $T_{3}$ contaminant in the original $T_{4}$ injection dose, no net correction was made. In actuality, no net correction was necessary in most of our calculations of $\left[\mathrm{T}_{3}\right]$. For example: to $10 \mathrm{ml}$ serum of $\mathrm{J}$. Mu. trace amounts of ${ }^{131} \mathrm{I}$-labeled $\mathrm{T}_{3}$ standard were added. To another $10 \mathrm{ml}$ serum of $\mathrm{J}$. Mu. trace amounts of a ${ }^{3} \mathrm{H}$-labeled $\mathrm{T}_{4}$ standard were added. After all the chromatographic manipulations, $62 \mathrm{dpm}$ of ${ }^{3} \mathrm{H}$ was recovered from the $\mathrm{T}_{3}$ area of the final paper chromatogram or $0.48 \%$ of the total ${ }^{3} \mathrm{H}$ activity applied to the paper. From the same $\mathrm{T}_{3}$ area, $55 \mathrm{dpm}$ of ${ }^{14} \mathrm{C}$ activity was recovered. The over-all $\mathrm{T}_{3}$ recovery calculated from the ${ }^{131} \mathrm{I}^{\mathrm{T}_{3}}$ standard was $17.7 \%$. Since the per cent of ${ }^{3} \mathrm{H}$-labeled $\mathrm{T}_{3}$ contaminant in the original injection dose of ${ }^{3} \mathrm{H}-\mathrm{T}_{4}$ was approximately the same $(0.50 \%)$ as that recovered in the $T_{3}$ area, no correction for artifacts was made. Therefore, the serum concentration of ${ }^{14} \mathrm{C}$ labeled $\mathrm{T}_{3}=5.5 \mathrm{dpm} \div 17.7 \times 100=31 \mathrm{dpm} \mathrm{ml} \mathrm{m}^{-1}$. The chromatographic data are summarized in Table II.

From sera collected during $\mathrm{L}$-[tyrosyl- $\left.-{ }^{14} \mathrm{C}\right] \mathrm{T}_{4}$ injections the $\left[\mathrm{T}_{4}\right]$ value or the amount of $\mathrm{L}$-[tyrosyl $\left.-{ }^{14} \mathrm{C}\right]$ $\mathrm{T}_{4}$ remaining in the body at time $t$ was calculated from equation (2), $\left[\mathrm{T}_{4}\right]=\mathrm{A} / \mathrm{K}_{4}\left(1-\mathrm{e}^{-\mathrm{K}_{4} \mathrm{t}}\right)$. The extrathyroidal conversion rate, $\lambda$, was calculated from equation (8), $\lambda=\left(\mathrm{K}_{3}\left[\mathrm{~K}_{3}-\mathrm{K}_{4}\right]\right) /\left(\mathrm{K}_{3}-\mathrm{K}_{4}\left[1-\mathrm{e}^{-\mathrm{K}_{3} \mathrm{t}}\right] /\right.$ $\left.\left[1-\mathrm{e}^{-\mathrm{K}_{4} t}\right]\right)\left[\mathrm{T}_{3}\right] /\left[\mathrm{T}_{4}\right]$. From sera collected after all 10 injections of $L$-[tyrosyl- $\left.{ }^{14} \mathrm{C}\right] \mathrm{T}_{4},\left[\mathrm{~T}_{4}\right]$ was calculated from equation (4), $\left[\mathrm{T}_{4}\right]=\mathrm{A} / \mathrm{K}_{4}\left(1-\mathrm{e}^{-\mathrm{K}_{4} \mathrm{t}^{*}}\right) \mathrm{e}^{\mathrm{K}_{4}\left(\mathrm{t}^{*}-\mathrm{t}\right)}$, and $\lambda$ from equation (9),

$$
\lambda=\frac{\mathrm{K}_{3}\left(\mathrm{~K}_{3}-\mathrm{K}_{4}\right)}{\mathrm{K}_{3}-\mathrm{K}_{4}\left(\frac{\mathrm{e}^{\mathrm{K}_{3} \mathrm{t}^{*}}-1}{\mathrm{e}^{\mathrm{K}_{4} \mathrm{t}^{*}}-1}\right) \mathrm{e}^{-\left(\mathrm{K}_{3}-\mathrm{K}_{4}\right) \mathrm{t}}} \frac{\left[\mathrm{T}_{3}\right]}{\left[\mathrm{T}_{4}\right]} .
$$

However, for interest of comparison, $\left[\mathrm{T}_{4}\right]$ values calculated from two other methods are listed in Table III along with those calculated from equations (2) and (4). In one of the methods the serum concentration of $\mathrm{L}$-[tyrosyl- $\left.{ }^{14} \mathrm{C}\right] \mathrm{T}_{4}$ was obtained from the ${ }^{14} \mathrm{C}$ activity found in the $T_{4}$ area of the final paper chromatogram and the over-all $T_{4}$ recovery. In turn, $\left[T_{4}\right]$ was calculated from the serum $\mathrm{L}-\left[\right.$ tyrosyl $\left.-{ }^{14} \mathrm{C}\right] \mathrm{T}_{4}$ concentration and the known volume of distribution of $\mathrm{T}_{4}$. As shown in Table III, the $\left[\mathrm{T}_{4}\right]$ values derived by this method
TABLE II

$T_{3}$ Radioactivities on the Paper Chromatograms in the Sera and in the Body, $\left[T_{3}\right]$, at Time $t$

\begin{tabular}{|c|c|c|c|c|c|}
\hline \multirow[b]{2}{*}{ Subject } & \multirow[b]{2}{*}{$\begin{array}{l}\text { Experi- } \\
\text { ment }\end{array}$} & \multirow[b]{2}{*}{ Time } & \multicolumn{3}{|c|}{$T_{3}$ radioactivities } \\
\hline & & & $\begin{array}{l}\text { Chromato- } \\
\text { grams }\end{array}$ & Sera & $\begin{array}{c}\text { Total } \\
\text { pool } \\
{\left[T_{8}\right]}\end{array}$ \\
\hline & & day & $\begin{array}{c}d p m T_{3} \\
\text { area }^{-1}\end{array}$ & $\begin{array}{l}d p m \\
m l^{-1}\end{array}$ & $d p m \times 10^{5}$ \\
\hline \multirow[t]{6}{*}{ J. McD. } & 1 & 16.0 & 31.8 & 14.4 & 6.404 \\
\hline & 2 & 20.0 & 52.8 & 12.3 & 5.487 \\
\hline & 3 & 20.5 & 30.5 & 7.1 & 3.168 \\
\hline & 4 & 21.0 & 49.7 & 11.6 & 5.162 \\
\hline & 5 & 21.5 & 27.3 & 6.4 & 2.835 \\
\hline & 6 & 22.0 & 28.0 & 6.5 & 2.910 \\
\hline \multirow[t]{9}{*}{ B. H. } & 1 & 8.0 & 31.3 & 13.2 & 5.027 \\
\hline & 2 & 16.0 & 84.4 & 19.3 & 7.334 \\
\hline & 3 & 16.5 & 64.2 & 14.7 & 5.586 \\
\hline & 4 & 17.0 & 125.4 & 28.7 & 10.906 \\
\hline & 5 & 17.5 & 50.4 & 11.5 & 4.370 \\
\hline & 6 & 18.0 & 111.2 & 25.4 & 9.652 \\
\hline & 7 & 18.5 & 105.6 & 24.1 & 9.158 \\
\hline & 8 & 19.0 & 101.6 & 23.2 & 8.816 \\
\hline & 9 & 20.0 & 84.0 & 19.2 & 7.296 \\
\hline \multirow[t]{8}{*}{ D. V. } & 1 & 8.0 & 53.9 & 34.8 & 12.013 \\
\hline & 2 & 16.0 & 40.5 & 9.3 & 3.195 \\
\hline & 3 & 16.5 & 50.8 & 11.6 & 4.005 \\
\hline & 4 & 17.0 & 33.9 & 7.8 & 2.674 \\
\hline & 5 & 17.5 & 32.5 & 7.4 & 2.563 \\
\hline & 6 & 18.0 & 42.9 & 9.8 & 3.384 \\
\hline & 7 & 19.0 & 21.1 & 4.8 & 1.663 \\
\hline & 8 & 20.0 & 15.6 & 3.6 & 1.232 \\
\hline \multirow[t]{7}{*}{ D. D. } & 1 & 12.0 & 108.4 & 40.3 & 18.735 \\
\hline & 2 & 17.0 & 54.7 & 19.2 & 8.947 \\
\hline & 3 & 17.5 & 69.7 & 23.2 & 10.807 \\
\hline & 4 & 18.0 & 104.1 & 34.7 & 16.145 \\
\hline & 5 & 18.5 & 73.9 & 24.6 & 11.458 \\
\hline & 6 & 19.0 & 95.8 & 32.0 & 14.857 \\
\hline & 7 & 20.0 & 79.2 & 26.4 & 12.281 \\
\hline D. G. & 1 & 20.0 & 27.3 & 8.6 & 3.694 \\
\hline J. Mu. & 1 & 10.0 & 55.4 & 31.2 & 13.429 \\
\hline
\end{tabular}

9-20 $\mathrm{ml}$ of the serum samples were applied to the column for deproteinization. The over-all recovery of $T_{2}$ after chromatographies was $17.2-31.8 \%$. The $T_{3}$ radioactivity in serum $\left(\mathrm{dpm} \mathrm{ml}^{-1}\right)=T_{3}$ radioactivity on paper chromatogram $(\mathrm{dpm}) \div$ total serum volume used $(\mathrm{ml}) \div$ per cent of $\mathrm{T}_{3}$ recovery $\times 100$. $T_{3}$ radioactivity in the body $(\mathrm{dpm})=T_{3}$ radioactivity in serum $\left(\mathrm{dpm} \mathrm{ml} \mathrm{m}^{-1}\right) \times \mathrm{T}_{3}$ volume of distribution $(1) \times 1,000$.

agree with those calculated from equations (2) and (4) in most instances. The other method estimated $\left[\mathrm{T}_{4}\right]$ by serially subtracting the urinary and fecal recoveries of ${ }^{14} \mathrm{C}$ from the total $\mathrm{L}$-[tyrosyl $\left.-{ }^{14} \mathrm{C}\right] \mathrm{T}_{4}$ injected. As seen in Table III, because of the unavoidable loss of specimen during any long term collection, this last method vastly overestimates the amount of $L-\left[\right.$ tyrosyl $\left.-{ }^{14} \mathrm{C}\right] \mathrm{T}_{4}$ remaining in the body.

In four of the eight subjects, kinetic studies of both $T_{4}$ and $T_{3}$ were carried out. The results are shown in Table IV. The results from the $T_{4}$ studies showed a mean half-time $\left(t \frac{1}{2}\right)$ of the disappearance of ${ }^{14} \mathrm{C}$ from serum, $5.62 \pm 1.21$ days (mean $\pm \mathrm{SD}$ ). The mean fractional turnover-rate $(\mathrm{K})$ was $12.93 \pm 2.62 \%$ per day. 
TABLE III

Estimated $L-\left[T y r o s y l-{ }^{14} C\right] T_{4}$ in the Body, $\left[T_{4}\right], D P M \times 10^{5}$

\begin{tabular}{|c|c|c|c|c|}
\hline Subject & $\begin{array}{c}\text { Experi- } \\
\text { ment }\end{array}$ & Method 1 & Method 2 & Method 3 \\
\hline \multirow{6}{*}{ J. McD. } & 1 & 120.8 & 111.3 & 188.0 \\
\hline & 2 & 84.9 & 121.6 & 177.1 \\
\hline & 3 & 81.2 & 105.5 & 177.1 \\
\hline & 4 & 77.7 & 104.3 & 173.8 \\
\hline & 5 & 74.3 & 66.9 & 167.0 \\
\hline & 6 & 71.1 & 77.6 & 163.8 \\
\hline \multirow[t]{9}{*}{ B. H. } & 1 & 220.2 & 275.4 & 221.7 \\
\hline & 2 & 111.0 & 186.6 & 294.5 \\
\hline & 3 & 103.8 & 154.4 & 287.9 \\
\hline & 4 & 97.1 & 231.3 & 281.4 \\
\hline & 5 & 90.9 & 142.0 & 275.1 \\
\hline & 6 & 85.0 & 175.7 & 271.1 \\
\hline & 7 & 79.5 & 155.6 & 266.1 \\
\hline & 8 & 74.4 & 140.9 & 266.1 \\
\hline & 9 & 65.1 & 132.8 & 260.7 \\
\hline \multirow[t]{8}{*}{ D. V. } & 1 & 193.8 & 233.6 & 202.6 \\
\hline & 2 & 75.1 & 66.2 & 255.6 \\
\hline & 3 & 68.2 & 61.5 & 250.3 \\
\hline & 4 & 61.1 & 52.9 & 238.7 \\
\hline & 5 & 57.9 & 50.5 & 231.6 \\
\hline & 6 & 53.1 & 43.1 & 220.4 \\
\hline & 7 & 44.6 & 41.5 & 217.8 \\
\hline & 8 & 37.5 & 32.8 & 206.7 \\
\hline \multirow[t]{7}{*}{ D. D. } & 1 & 316.3 & 413.5 & 535.1 \\
\hline & 2 & 158.2 & 484.6 & 429.2 \\
\hline & 3 & 147.6 & 158.7 & 428.4 \\
\hline & 4 & 137.7 & 164.1 & 42.3 .2 \\
\hline & 5 & 128.5 & 153.2 & 41.9 .8 \\
\hline & 6 & 119.9 & 156.9 & 415.2 \\
\hline & 7 & 104.4 & 191.2 & 407.3 \\
\hline D. G. & 1 & 86.4 & 183.0 & 71.5 \\
\hline J. Mu. & 1 & 250.0 & 266.7 & 216.2 \\
\hline
\end{tabular}

Estimation of the amount of injected $\mathrm{L}-[$ tyrosyl-14 $\mathrm{C}] \mathrm{T}_{4}$ remaining in the body at time $t,\left[\mathrm{~T}_{4}\right]$, by three different methods. Method 1 used the equations (2) and (4). Method 2 used the serum concentration of $\mathrm{L}-\left[\right.$ tyrosyl- $\left.{ }^{14} \mathrm{C}\right] \mathrm{T}_{4}$ and the volume of distribution of $T_{4}$. Method 3 used subtraction of the ${ }^{14} \mathrm{C}$ recovery from excreta from the total amount of L-[tyrosyl-14 $\mathrm{C}^{-} \mathrm{T}_{4}$ injected.

The mean zero time volume of distribution $\left(V_{d}\right)$ was $10.1 \pm 1.8$ liters. The average extrathyroidal pool of $\mathrm{T}_{4}$ was $635.0 \pm 130.0 \mu \mathrm{g}$ (total $\mathrm{T}_{4}$ ) which resulted in a mean $\mathrm{T}_{4}$ production rate of $82.4 \pm 25.7 \mu$ g per day.

In the same four subjects the results of the $T_{3}$ kinetic study showed a mean half-time of $0.92 \pm 0.11$ days (mean $\pm \mathrm{SD}$ ). The average fractional turnoverrate of $T_{3}$ was $76.12 \pm 7.16 \%$ per day. The average zero time volume of distribution of $\mathrm{T}_{3}$ was $40.9 \pm 4.8$ liters. The mean extrathyroidal pool of $\mathrm{T}_{3}$ was $74.8 \pm 15.8 \mu \mathrm{g}$.
Lastly, the mean daily production rate of $\mathrm{T}_{3}$ was $57.4 \pm 14.7 \mu \mathrm{g}$.

Sufficient data were available to calculate the extrathyroidal conversion rate of $\mathrm{T}_{4}$ to $\mathrm{T}_{3}, \lambda$, in six of the subjects. Analyses were carried out in six to nine samples of serum from each subject in the majority of instances. The results of $\lambda$ calculated by equations (2) and (8) or equations (4) and (9) gave essentially similar results. They were grouped together in Table V. The mean conversion rate from the entire group of six subjects was $4.16 \pm 1.44 \%$ of extrathyroidal $\mathrm{T}_{4}$ pool per day (mean $\pm \mathrm{SD}$ ), or $33.4 \pm 11.0 \%$ of $\mathrm{T}_{4}$ production per day. In four of the six subjects the amount of $\mathrm{T}_{3}$ generated by the pathway of extrathyroidal conversion was calculated with each subject's own kinetics of $T_{4}$ and $\mathrm{T}_{3}$. For the remaining two subjects, the amount of $\mathrm{T}_{3}$ converted from $\mathrm{T}_{4}$ was calculated with the mean values obtained from the other four subjects. The results showed that $26.1 \pm 9.5 \mu \mathrm{g}$ of thyroxine was metabolized each day by the pathway of extrathyroidal conversion which gave rise to an average of $21.9 \pm 7.9$ $\mu \mathrm{g}$ of $\mathrm{T}_{3}$. The amount of $\mathrm{T}_{3}$ thus derived constituted an average of $31.0 \pm 14.7 \%$ of the total extrathyroidal pool of $\mathrm{T}_{3}$. More important, it constituted an average of $41.2 \pm 20.9 \%$ of the daily production rate of $\mathrm{T}_{3}$.

\section{DISCUSSION}

In the past, in vivo evidence of extrathyroidal conversion of $T_{4}$ to $T_{3}$ were sought by many studies in animals and in man. Most of these studies employed the technique of administering radiothyroxine in one injection, and then the presence or absence of radioactive $T_{3}$ was demonstrated by chromatography. The conclusions of most of these studies were equivocal and controversial (6). This controversy can be explained partly by the kinetics of $T_{3}$ itself. As shown by the results of our present study and that reported by other investigators, this hormone has a fractional turnover-rate of $70 \%$ per day and a half-time of approximately 1 day (17-20). After multiple injections of $\mathrm{L}$-[tyrosyl- $\left.{ }^{14} \mathrm{C}\right] \mathrm{T}_{4}$, the ${ }^{14} \mathrm{C}$ labeled $\mathrm{T}_{3}$ constituted only $1.6 \%$ of the total serum radioactivity. Therefore, demonstration of the extrathyroidal conversion of $T_{4}$ to $T_{3}$ amidst the multiple artifacts inherent of chromatographic techniques is fraught with pitfalls. (a) Thyroidal contribution of $\mathrm{T}_{3}$, (b) contamination of the $\mathrm{T}_{4}$ dose by $\mathrm{T}_{3},(c)$ incomplete separation of the $\mathrm{T}_{4}$ and $\mathrm{T}_{3}$ fractions, and $(d)$ artifactual production of $\mathrm{T}_{3}$ during chromatography are some of the pitfalls.

The procedures followed in our present study were adopted to overcome these very pitfalls. The radiothyroxines used in the study were labeled with ${ }^{14} \mathrm{C}$ or ${ }^{3} \mathrm{H}$ rather than with a radioiodine, therefore the thyroidal contribution of $T_{3}$ in blood was excluded from our calculation. The $\mathrm{L}$-[tyrosyl- $\left.{ }^{14} \mathrm{C}\right] \mathrm{T}_{4}$ doses were chromato- 
TABLE IV

Kinetic Studies of $T_{4}$ and $T_{3}$ in the Same Subjects

\begin{tabular}{|c|c|c|c|c|c|c|}
\hline \multicolumn{2}{|c|}{ Patients } & \multirow{2}{*}{$\begin{array}{c}\text { ts } \\
d a y \\
7.85\end{array}$} & \multirow{2}{*}{$\begin{array}{c}\mathrm{K} \\
\% \text { day }^{-1} \\
8.83\end{array}$} & \multirow{2}{*}{ 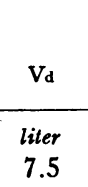 } & \multirow{2}{*}{$\begin{array}{c}\begin{array}{c}\text { Extra- } \\
\text { thyroidal } \\
\text { pool }\end{array} \\
\mu g \\
600.0\end{array}$} & \multirow{2}{*}{$\begin{array}{c}\begin{array}{c}\text { Production } \\
\text { rate }\end{array} \\
\mu g d a y^{-1} \\
53.0\end{array}$} \\
\hline Thyroxine & J. McD. & & & & & \\
\hline & B. $\mathrm{H}$. & 5.19 & 13.35 & 12.5 & 875.0 & 116.8 \\
\hline & D. V. & 3.99 & 17.35 & 10.2 & 663.0 & 115.0 \\
\hline & D. D. & 5.00 & 13.86 & 10.0 & 450.0 & 62.4 \\
\hline & D. G. & 6.30 & 11.00 & $10.1^{*}$ & 556.0 & 61.2 \\
\hline & J. Mu. & 5.37 & 12.91 & $10.1^{*}$ & 665.0 & 85.9 \\
\hline & Mean & 5.62 & 12.93 & 10.1 & 635.0 & 82.4 \\
\hline & $\pm \mathrm{SD}$ & 1.21 & 2.62 & 1.8 & 130.0 & 25.7 \\
\hline \multirow{8}{*}{$\begin{array}{l}\text { Triiodo- } \\
\text { thyronine }\end{array}$} & J. McD. & 0.86 & 80.35 & 44.5 & 102.4 & 82.3 \\
\hline & B. H. & 0.98 & 70.50 & 38.0 & 60.8 & 42.9 \\
\hline & D. V. & 1.06 & 65.48 & 34.5 & 56.9 & 37.3 \\
\hline & D. D. & 0.79 & 88.13 & 46.5 & 65.1 & 57.4 \\
\hline & D. G. & $0.92^{*}$ & $76.12^{*}$ & $40.9^{*}$ & 77.7 & 59.2 \\
\hline & J. Mu. & $0.92^{*}$ & $76.12^{*}$ & $40.9^{*}$ & 85.9 & 65.4 \\
\hline & Mean & 0.92 & 76.12 & 40.9 & 74.8 & 57.4 \\
\hline & $\pm \mathrm{SD}$ & 0.11 & 7.16 & 4.8 & 15.8 & 14.7 \\
\hline
\end{tabular}

$t_{k}$, the half-time of the radioactivity disappearance from serum. $K$, the fractional turnover-rate. $V_{d}$, zero time volume of distribution. Each mean of the group is shown with its standard deviation.

* No study was carried out for this subject and the value was not included in the mean.

graphed at the beginning and the end of injection period to determine the exact amounts of contamination by ${ }^{14} \mathrm{C}$-labeled $\mathrm{T}_{3}$ which was a very small correction in the present study since most of the sera were collected 5 days after the last ${ }^{14} \mathrm{C}-\mathrm{T}_{4}$ injection. As shown in Fig. 3, when serial blood samples were collected after an injection of $\mathrm{D}, \mathrm{L}-\left[\alpha, \beta-{ }^{3} \mathrm{H}\right] \mathrm{T}_{4}$, the ${ }^{3} \mathrm{H}$ activity in the $\mathrm{T}_{3}$ fraction of blood rose with time suggesting that thc formation of ${ }^{3} \mathrm{H}-\mathrm{T}_{3}$ was primarily due to metabolie events. If the ${ }^{3} \mathrm{H}$ radioactivity in the $\mathrm{T}_{3}$ fraction was solely due to contamination of the $T_{4}$ dose by $T_{3}$, the ${ }^{3} \mathrm{H}$ activity should have cleared at the same rate as

TABLE V

The Extrathyroidal Conversion Rates of $T_{4}$ to $T_{3}(\lambda)$

\begin{tabular}{|c|c|c|c|c|c|}
\hline \multirow[b]{2}{*}{ Subjects } & \multirow[b]{2}{*}{$\begin{array}{l}\text { Experi- } \\
\text { ments }\end{array}$} & \multicolumn{2}{|c|}{$\% T_{4}$ metabolized per day } & \multicolumn{2}{|c|}{$\% \mathrm{~T}_{3}$ generated per day } \\
\hline & & $\begin{array}{c}\text { Extrathyroidal } \\
\text { pool }\end{array}$ & $\begin{array}{l}\text { Production } \\
\text { rate }\end{array}$ & $\begin{array}{c}\text { Extrathyroidal } \\
\text { pool }\end{array}$ & $\begin{array}{l}\text { Production } \\
\text { rate }\end{array}$ \\
\hline J. McD. & 6 & $3.6 \pm 0.8$ & 40.8 & 17.7 & 22.0 \\
\hline B. $\mathrm{H}$. & 9 & $4.9 \pm 1.9$ & 36.9 & 59.3 & 84.0 \\
\hline D. V. & 8 & $2.5 \pm 1.0$ & 14.5 & 24.5 & 37.4 \\
\hline D. D. & 7 & $6.8 \pm 1.9$ & 48.8 & 39.1 & 44.4 \\
\hline D. G. & 1 & 2.8 & 25.3 & 16.6 & 21.8 \\
\hline J. Mu. & 1 & 4.4 & 34.4 & 28.8 & 37.8 \\
\hline \multicolumn{2}{|c|}{ Mean \pm SD } & $4.2 \pm 1.4$ & $33.4 \pm 11.0$ & $31.0 \pm 14.7$ & $41.2 \pm 20.9$ \\
\hline
\end{tabular}

$\lambda$, the extrathyroidal conversion rate. The results of the first four subjects were calculated from their own kinetic data (Table IV). The results of the last two subjects were calculated from the mean values of the first four subjects listed in Table IV. 
${ }^{14} \mathrm{C}-\mathrm{T}_{3}$ and the ${ }^{3} \mathrm{H} /{ }^{14} \mathrm{C}$ ratios in the $\mathrm{T}_{3}$ fraction should not have risen with time. The problems of incomplete separation of $T_{4}$ and $T_{3}$ fractions and the in vitro conversion of $T_{4}$ to $T_{3}$ are inherent of column and paper chromatographies. The contributions of these artifacts to our ${ }^{14} \mathrm{C}-\mathrm{T}_{3}$ measurements were partly corrected for by the addition of $\mathrm{D}, \mathrm{L}-\left[\alpha, \beta-{ }^{3} \mathrm{H}\right] \mathrm{T}_{4}$ to serum samples in our study. At least part of the ${ }^{3} \mathrm{H}$ radioactivity in the $\mathrm{T}_{3}$ fraction was the combined result from the $\mathrm{D}, \mathrm{L}-\left[\alpha, \beta{ }^{3} \mathrm{H}\right] \mathrm{T}_{4}$ that remained in the $\mathrm{T}_{3}$ fraction and the $\mathrm{D}, \mathrm{L}-\left[\alpha, \beta-{ }^{3} \mathrm{H}\right] \mathrm{T}_{3}$ that was formed artifactually. Therefore, the ${ }^{3} \mathrm{H}$ activity in the $\mathrm{T}_{3}$ fraction was used to correct for the ${ }^{14} \mathrm{C}$ radioactivity in the $\mathrm{T}_{3}$ fraction which was due to the contaminating $\mathrm{L}-\left[\right.$ tyrosyl- $\left.{ }^{14} \mathrm{C}\right] \mathrm{T}_{4}$ and the in vitro production of $\mathrm{L}-\left[\right.$ tyrosyl $\left.-^{14} \mathrm{C}\right] \mathrm{T}_{3}$. When these corrections were applied, the net ${ }^{14} \mathrm{C}$ radioactivity in the $T_{3}$ fraction was never negative in any sample drawn $48 \mathrm{hr}$ after an injection of radiothyroxin. Our results convincingly showed that the pathway of extrathyroidal conversion of $T_{4}$ to $T_{3}$ is operative in normal man and they support the recent report of Braverman et al (9).

All our serum samples were analyzed by two-dimensional chromatography at the final stage of study. A solvent of hexane : tertiary amyl alcohol: ammonia was used in developing the chromatograms in both directions because this solvent system is particularly suitable in the separation of $T_{4}, T_{3}$, Tetrac, and triiodothyroacetic acid (21). The metabolism of $\mathrm{T}_{4}$ to Tetrac was observed in animals by many observers before (22-24) and was also observed by Braverman et al. in man (9). Our results agreed with the last report and showed that in a state of near isotopic equilibrium, ${ }^{14} \mathrm{C}$-labeled Tetrac was found in equal or slightly larger amounts than ${ }^{14} \mathrm{C}$-labeled $\mathrm{T}_{3}$. Since the clearance rate of Tetrac was reported to be slower than that of $\mathrm{T}_{3}$ by some early studies, the higher serum concentrations of ${ }^{14} \mathrm{C}$-labeled Tetrac could not be interpreted to mean a higher production rate for Tetrac than for $\mathrm{T}_{3}$ in man (25). Recently, Pittman, Read, Chambers, and Nakafuji (13) administered a mixture of $\mathrm{D}, \mathrm{L}-\left[a, \beta-{ }^{3} \mathrm{H}\right] \mathrm{T}_{4}$ and another $\mathrm{T}_{4}$-labeled with ${ }^{14} \mathrm{C}$ in the phenolic ring to normal subjects. Approximately $50-60 \%$ of the radioactivity was eventually recovered from urine after $3 \mathrm{wk}$. The ${ }^{3} \mathrm{H} /{ }^{14} \mathrm{C}$ ratios of the urine were the same as the ${ }^{3} \mathrm{H} /{ }^{14} \mathrm{C}$ ratios of the $\mathrm{T}_{4}$ dose suggesting that the deiodinated metabolites of $T_{4}$ retained an intact diphenyl ether structure. Therefore, most likely the $T_{3}$ and Tetrac formed from $T_{4}$ metabolism are in turn deiodinated before urinary excretion without undergoing cleavage of the diphenyl ether.

Detailed study of the $T_{4}$ and $T_{3}$ kinetics were carried out in the same individual in four of our subjects. Our study of $\mathrm{T}_{4}$ showed a mean $\mathrm{t} \frac{1}{2}$ of 5.62 days, mean turnover-rate of $12.9 \%$ per day, mean zero time volume of distribution of 10.1 liter, mean extrathyroidal thyroxine pool $635 \mu \mathrm{g}$ (total $\mathrm{T}_{4}$ ) and mean daily production $82.4 \mu \mathrm{g}$. Despite the fact that our results were obtained from the mean of only four subjects, these values were essentially in agreement with the results published by Berson and Yalow; Ingbar and Freinkel; and Sterling and Chodos $(26,16,27)$. Our mean turnover-rate and production rate of $\mathrm{T}_{4}$ were slightly higher than the values given in literature which can be explained partly by the fact that our subjects were young and healthy and their values were obtained after approximately $70 \%$ of the extrathyroidal $\mathrm{T}_{4}$ pool was equilibrated with the injected ${ }^{14} \mathrm{C}-\mathrm{T}_{4}$.

Our study of $\mathrm{T}_{3}$ kinetics showed a mean $t_{2}^{\frac{1}{2}}$ of 0.92 per day, a mean fractional turnover-rate of $76.1 \%$ per day, a mean zero time volume of distribution 40.9 liter, a mean extrathyroidal $\mathrm{T}_{3}$ pool of $74.8 \mu \mathrm{g}$ (total $\mathrm{T}_{3}$ ) and a mean production rate of $57.4 \mu \mathrm{g}$. The formation of a ${ }^{131}$ I-labeled protein as a degradation product of injected $\mathrm{L}-\left[3^{\prime}-{ }^{131} \mathrm{I}\right] \mathrm{T}_{3}$ was reported only recently (17). Comparison of our results with the earlier reports is difficult but our results are in general agreement with the more recent reports of $T_{3}$ kinetics by Surks, Woeber, Nicoloff, and Cavalieri and their respective coworkers (17-20). Again, our values of the turnover-rate are slightly higher. Until recently measurements of stable $\mathrm{T}_{3}$ were not made widely. The absolute production rate or disposal rate of $\mathrm{T}_{3}$ were not reported by most investigators. Our value of $\mathrm{T}_{3}$ production rate agreed with that given by Woeber, Sobel, Ingbar, and Sterling $60 \mu \mathrm{g}$ per day (18). There are several reported methods for the measurement of stable $\mathrm{T}_{3}$ in serum employing column and paper chromatographies as well as gas-liquid chromatography $(14,28,29)$. The value of $\mathrm{T}_{3}$ in normal serum by these three methods is well above $200 \mathrm{ng}$ per $100 \mathrm{ml}$. However, there appeared to be no agreement on the value of stable $T_{3}$ in normal serum (30). Apparently no satisfactory correction for chromatographic artifacts as discussed earlier in this paper has been found. The stable serum $\mathrm{T}_{3}$ in our study was measured by a modified method of Sterling et al. (14) in the Boston Medical Laboratory, Waltham, Mass. Measured by this method the $T_{3}$ concentration in normal serum is $150-250 \mathrm{ng}$ per $100 \mathrm{ml}$ which must be taken as an approximation. However, for clinical purposes and in normal subjects this method has been found very reproducible. In the presence of elevated serum $T_{4}$, the measurement of $T_{3}$ becomes too high partly due to incomplete separation of the $T_{4}$ and $T_{3}$ fractions. Braverman et al. (9) reported that their athyreotic patients, whose serum $T_{4}$ measurements were elevated to 2-3 times the normal value, were eumetabolic despite serum $\mathrm{T}_{3}$ measurements in the range of $269-680 \mathrm{ng}$ per $100 \mathrm{ml}$ (9). This dis- 
crepancy can be explained partly by the fact that in the presence of excessive $T_{4}$, the $T_{4}$ contamination of the $T_{3}$ fraction becomes significant in displacement analysis and falsely elevates the $T_{3}$ measurements.

The sera studied were collected from our subjects both during and after the injection period of L-[tyrosyl$\left.{ }^{14} \mathrm{C}\right] \mathrm{T}_{4}$. While these different conditions required different methods of calculation, they yielded similar results. Our calculation yielded a mean extrathyroidal conversion rate of $T_{4}$ to $T_{3}, 4.16 \%$ of the extrathyroidal $\mathrm{T}_{4}$ per day. More significantly this pathway was shown to metabolize approximately $33 \%$ of the $\mathrm{T}_{4}$ produced daily. Therefore, approximately $22 \mu \mathrm{g}$ of $\mathrm{T}_{3}$ was generated from the extrathyroidal conversion of $T_{4}$. However the contribution of this $22 \mu \mathrm{g}$ of $\mathrm{T}_{3}$ to the over-all production of $T_{3}$ is more difficult to assess because of our reservation over the stable $T_{3}$ determinations. If these determinations were valid, then extrathyroidal conversion of $\mathrm{T}_{4}$ to $\mathrm{T}_{3}$ contributed $41 \%$ of the total daily production of $\mathrm{T}_{3}$.

In conclusion, our study conclusively shows that the pathways of extrathyroidal conversion of $T_{4}$ to $T_{3}$ and $\mathrm{T}_{4}$ to Tetrac are operative in normal men. The amount of $\mathrm{T}_{4}$ metabolized by this pathway accounts for $33 \%$ of the total $\mathrm{T}_{4}$ production and contributes $41 \%$ of the total $T_{3}$ production each day. Therefore, the extrathyroidal conversion of $T_{4}$ to $T_{3}$ is a physiologically important pathway in normal man.

\section{ACKNOWLEDGMENTS}

The authors wish to acknowledge the generous help given to us by Dr. Gerald A. Huchison of the Departments of Biomathematics and Engineering Biophysics of the University of Alabama in Birmingham.

This investigation was supported by Grants AM 018181, T1 AM 5058, and 2 M01-Fr 32 from the National Institutes of Health, Bethesda, Md.

\section{REFERENCES}

1. Gross, J., and R. Pitt-Rivers. 1952. The identification of of $3: 5: 3^{\prime}$-L-triiodothyronine in human plasma. Lancet. 1 : 439.

2. Taurog, A., J. C. Porter, and D. T. Thio. 1964. Nature of the ${ }^{131} \mathrm{I}$-compounds released into the thyroid veins of rabbits, dogs and cats, before and after TSH administration. Endocrinology. 74: 902.

3. Inoue, K., Y. Grimm, and M. A. Greer. 1967. Quantitative studies on the iodinated components secreted by the rat thyroid gland as determined by in situ perfusion. $E_{n}$ docrinology. 81 : 946.

4. Pitt-Rivers, R., J. B. Stanbury, and B. Rapp. 1955. Conversion of thyroxine to $3: 5: 3^{\prime}$-triiodothyronine in vivo. J. Clin. Endocrinol. Metab. 15: 616.

5. Lassiter, W. E., and J. B. Stanbury. 1958. The in vivo conversion of thyroxine to $3: 5: 3^{\prime}$-triiodothyronine. $J$. Clin. Endocrinol. Metab. 18: 903.
6. Volpert, E. M., R. Grinberg, and S. C. Werner. 1964. Metabolism of labeled thyroid hormone by thyrotropic and adrenotropic mouse pituitary tumors. Acta. Int. Contra. Cancrum. 20: 1137.

7. Albright, E. C., F. C. Larson, and R. H. Tust. 1954. In vitro conversion of thyroxine to triiodothyronine by kidney slices. Proc. Soc. Exp. Biol. Med. 86: 137.

8. Stanbury, J. B. 1960. Deiodination of the iodinated amino acids. Ann. N. Y. Acad. Sci. 86: 417.

9. Braverman, L. E., S. H. Ingbar, and K. Sterling. 1970. Conversion of thyroxine $\left(T_{4}\right)$ to triiodothyronine $\left(T_{3}\right)$ in athyreotic human subjects. J. Clin. Invest. 49: 855.

10. Pittman, C. S., H. Nakafuji, and V. H. Read. 1970. The metabolites of ${ }^{14} \mathrm{C}$ labeled thyroxine $\left(\mathrm{T}_{4}\right)$ in the blood of normal man. Clin. Res. 18: 75.

11. Shiba, T., and H. J. Cahnmann. 1962. Synthesis of specifically iodine-131- and carbon- ${ }^{14}$-labeled thyroxine. J. Org. Chem. $27: 1773$.

12. Nunez, J., C. Jacquemin, and J. Roche. 1962. Preparation de phenols trities, II. J. Appl. Radiat. Isotop. 13: 611.

13. Pittman, C. S., V. H. Read, J. B. Chambers, Jr., and H. Nakafuji. 1970. The integrity of the ether linkage during thyroxine metabolism in man. J. Clin. Invest. 49: 373.

14. Sterling, K., D. Bellabarba, E. S. Newman, and M. A. Brenner. 1969. Determination of triiodothyronine concentration in human serum. J. Clin. Invest. 48: 1150.

15. Murphy, B. E. P., and C. J. Pattee. 1964. Determination of thyroxine utilizing the property of protein-binding. J. Clin. Endocrinol. Metab. 24: 187.

16. Ingbar, S. H., and N. Freinkel. 1955. Simultaneous estimation of rates of thyroxine degradation and thyroid hormone synthesis. J. Clin. Invest. 34: 808.

17. 'Surks, M. I., and J. H. Oppenheimer. 1969. Formation of iodoprotein during the peripheral metabolism of $3,5,3^{\prime}$ triiodo-L-thyronine-125 I in the euthyroid man and rat. J. Clin. Invest. 48: 685 .

18. Woeber, K. A., R. J. Sobel, S. H. Ingbar, and K. Sterling. 1970. The peripheral metabolism of triiodothyronine in normal subjects and in patients with hyperthyroidism. J. Clin. Invest. $49: 643$.

19. Nicoloff, J. T., and J. Low. 1970. Triiodothyronine ${ }^{125} \mathrm{I}_{3}$ ) and thyroxine ( ${ }^{131} \mathrm{I} \mathrm{T}_{4}$ ) kinetics in man. Program of the 52nd Annual Meeting of the Endocrine Society, St. Louis, Mo. 93.

20. Cavalieri, R. R., M. Steinberg, and G. L. Searle. 1970. Metabolism of $T_{3}$ in Graves' disease. Program of the 6th International Thyroid Conference, Vienna, Austria. 48.

21. Bellabarba, D., R. E. Peterson, and K. Sterling. 1968. An improved method for chromatography of iodothyronines. J. Clin. Endocrinol. Metab. 28: 305.

22. Roche, J., R. Michel, and J. Tata. 1954. Sur le nature des combinaisons iodées excrétées par le foie et le rein après administration de L-thyroxine et de L-3:5:3'-triiodothyronine. Biochim. Biophys. Acta. 15: 500.

23. Albright, E. C., F. C. Larson, K. Tomita, and H. A. Lardy. 1956. Enzymatic conversion of thyroxine and triiodothyronine to the corresponding acetic acid analogues. Endocrinology. 59: 252.

24. Galton, V. A., and R. Pitt-Rivers. 1959. The identification of the acetic acid analogues of thyroxine and triiodothyronine in mammalian tissues. Biochem. J. $72: 319$.

25. Green, W. L., and S. H. Ingbar. 1961. The peripheral 
metabolism of tri- and tetraiodothyroacetic acids in man. J. Clin. Endocrinol. Metab. 21: 1548.

26. Berson, S. A., and R. S. Yalow. 1954. Quantitative aspects of iodone metabolism. The exchangeable organic iodine pool, and the rates of thyroidal secretion, peripheral degradation, and fecal excretion of endogenously synthesized organically bound iodine. J. Clin. Invest. 33: 1533.

27. Sterling, K., and R. B. Chodos. 1956. Radiothyroxine turnover studies in myxedema, thyrotoxicosis, and hypermetabolism without endocrine disease. J. Clin. Invest. $35: 806$.
28. Nauman, J. A., A. Nauman, and S. C. Werner. 1967. Total and free triodothyronine in human serum. J. Clin. Invest. 46: 1346.

29. Hollander, C. S. 1968. On the nature of the circulating thyroid hormone: Clinical studies of triiodothyronine and thyroxine in serum using gas chromatographic methods. Trans. Ass. Amer. Physicians Philadelphia. 81: 76.

30. Bellabarba, D., and K. Sterling. 1969. Formation of Esters of thyroxine and triiodothyronine during alcoholic extraction. J. Clin. Endocrinol. Metab. 29: 1510. 